\title{
HLA-DPB1*0401 Positive Cells Present
}

National Cancer Institute

\section{Source}

National Cancer Institute. HLA-DPB1*0401 Positive Cells Present. NCI Thesaurus. Code C146725.

An indication that cells expressing HLA-DPB1*0401 have been detected in a sample. 